\title{
EVALUATION OF THE EFFECTIVENESS OF THE IMO STATE FISHERIERS EXTENSION PROGRAMME.
}

\section{OHAJIANYA D.O, ONU D.O, AND ECHETAMA J.A.}

\section{ABSTRACT}

This study evaluated the Imo State Ministry of Agriculture Fisheries Extension Programmes. Questionnaires were used to collect data from 15 randomly selected extension staff and 200 proportionately selected fish farmers from the three fisheries zones of the state between November 1997 and February 1998. Data were analysed using descriptive statistics, Z-test and multiple regressiion analysis. Results show that the fisheries extension service made successful initial educational contact with a reasonable number of fish farmers, but the regularity of contact and provision of needed fisheries input was below expectation leading to low level of adoption of fisheries technologies. Adoption behaviour of fish farmers was significantly related to most of the personal and farm enterprise characteristics of farmers. The success of agricultural policies on sustainable productivity and fisheries development in Nigeria depends to a large extent on the consideration of the important personal and farm enterprise characteristics of fish farmers which influence technology adoption.

\section{INTRODUCTION}

Food Production in Nigeria is not keeping pace with the rapid population growth (FAO, 1970), leading to malnutrition among the rural population. To improve dietary quality, the protein intake in our food, espeically animal protein should be stepped up (Brown,1963). The protein intake from animal sources, which is less than $10 \mathrm{gm} /$ capita /day for the average Nigerian is far less than the $20 \mathrm{gm} /$ capita/day minimum amount recommended by FAO for the daily maintenance of good health (David -West, 1982). Livestock and fish are the major sources of 
this animal protein in the Nigerian Food basket. Obviously, livestock production alone cannot provide the animal protein needs of about 100 million Nigerians. This, therefore calls for the encouragement of fish production as a supplement, especially as they are more efficient converters of food intakes than most domesticated animals (Borgstorm, 1991). Fish contributes about 12 percent of the total animal protein supply of the World population (Borgstorm, 1991), and supplies animal protein compared to about 45 percent of all forms of meat (FAO, 1981). They were convinced that the achievements 45 percent of all forms of meat (FAO, 1981). They were convinced that the achievements of food sufficiency in quality and quantity can only be achieved with increased production of fish and fish products through effective fisheries extension efforts, and recommended the institution of an effective reversible tripartite educational agency that ensures interactions between research, extension services and the fishermen for sustainable fisheries development. This tripartite agency relationship has existed in Imo State since 1975, but little is known about how far it has achieved the objectives of increased fisheries production in the state.

It may be errorneous to assume that the educational programme of the various extension services in Nigeria are performing well. Past studies by Akinbode (1976) and Obibuaku and Hursh (1983) have revealed that the performance of most Nigerian extension services have not been satisfactory, while records of success have also been established by others (Ekpere, 1976; Asiabaka, 1995).

\section{Theoretical Framework}

Extension evaluation is the process of determining behaviours of the people and extension teachers; and the degree to which changes in behaviour are actually taking place (Tyler, 1950). Kesley and Hearne (1965), also highlighted that evaluation determines how accurately and clearly objectives of a programme have been stated, to what extent they have been attained and whether action is proceeding in the right 
direction. Blackenburg (1994) reported that a majority of extension services do not scientifically and systematically evaluate their work, especially where the extension service is a government agency and has possibly a monopoly position, such that the clients hardly exert any pressure for the extension instrument to be economically used. But Machenna (1981) believes that evaluation is dynamic and essential because it enables one to make correct judgement about programmes and theory of effectiveness, the clientele, extension educators, the public and private funding agencies.

The most useful tool for evaluating on-going programme as recommended by Machenna (1981) is the Provous discrepancy evaluation model (figure 1), described as being marvellous, versatile and easy to use, and which fits both carefully planned programme and those that just grew. The model has three basic phases; Discrepancy to mean difference, (ii) Programme perfornance, and (iii) Programme design standard or objective.

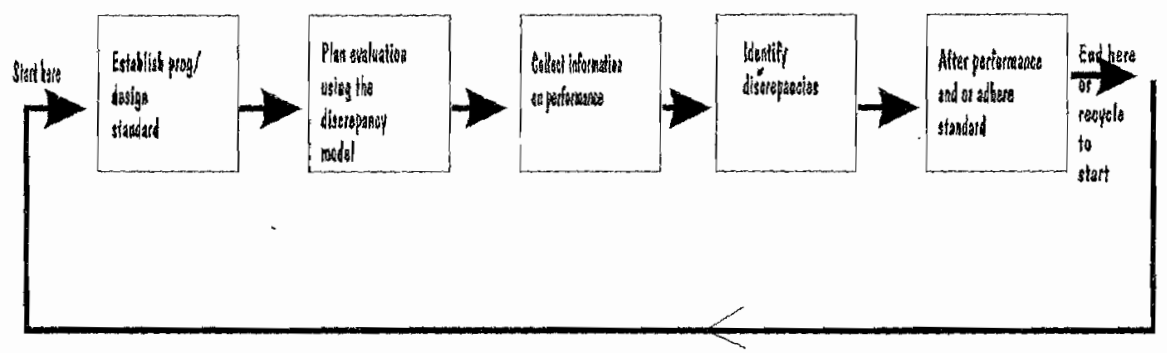

Figure 1: Discrepancy Evaluation Model

Other evaluation models like those of Davie (1975), and Steel (1975) can also help guide responsive, accountable, people-centred evaluation of extension programmes, with one of the models 
assumptions being that the involvement of all key interested people in the establishment of their concerns, needs, values, goals and other criteria will more likely evolve a better programme than the mere use of prestructured or standardized evaluation designs.

Young and Cannigham (1977) in Ohio developed an instrument $t$ o measure extension output. They used the clientele who as participants in extension progrmmes would have an opinion about what constitutes a good programme.

Assessment of programmes based on written reports and staff activities along is not very fruitful in programme evaluation. This is why it is recommended that information from farm families and the farms should also be collected and used. Kanter (1982) found out that in Pennsyvania, extension agents rated extension programmes higher than any other group such as extension clientele, executive committee members and administrators, and reported that extension agents should not be the only group to be used in evaluating extension programmes.

An extension programme is evaluated to be effective if it successfully produced the desired effect. Cornea and Tepping (1977) defined effectiveness as the yardstick for measuring the merit or worth of a programme, while Seepersad and Henderson (1984) defined same as the extent to which the programme met some or all of the goals or objectives.

Indicators used for measuring effectiveness may be in the form of; the number of women farmers who adopt a particular practice, the number of contact farmers reached by the extension worker, the number of visits made by the extension worker, yields of crops, changes in cropping intensity and patterns, and spread of key practices (Bennett, 1977).

Effectiveness should be based on the basic intent and objectives of a programme. If a programme was developed in response to a particular need, a major concern of the assessment should be 
whether the programme is meeting the need, or to what extent it met the need, and if the programme met the desired needs, it would be regarded as an effective programme. In this study, fish farmers and extension workers were interviewed using the provous discrepancy evaluation model and, the level of adoption of the recommended improved fisheries technologies by the fish farmers is the measure of programme effectiveness.

\section{Objectives of the Study}

This study evaluated the effectiveness of the Imo State Agricultural Development Project (ADP) fisheries extension programme in helping fish farmers increase fish production.

The study specifically:

(i) determined the levels of adoption of recommended fisheries technologies by the ADP contact and non-ADP contact fish farmers, (ii) examined the factors affecting the effectiveness of fisheries extension programme, and

(iii) identified the constraints to fisheries development in the state.

\section{Hypotheses:}

The following null hypotheses were developed for statistical testing:

(i) Imo State fisheries extension programme has no significant difference on the impact made on the different fish farmer categories (ii) There is no significant relationship between fish farmers' personal and farm enterprises characteristics and their levels of adoption of improved fisheries technologies.

\section{METHODOLOGY}

The study covered fish farmers and fisheries extension staff of the Ministry of Agriculture from the three fisheries zones of Owerri, Orlu and Okigwe in Imo State. The sampling frame were the lists of members of fish famers co-operatives provided by the Zonal offices of 
the Imo State agricultural extension service; non - members of fish farmers co-operatives and extension contact fish farmers provided by the resident agricultural extension agents; and the extension staff in the three fisheries zones of the state provided by the zonal offices. Multistage stratified sampling procedure was adopted in selecting 200 fish farmers comprising 177 members and 23 non-members of fish farmers co-operatives, while random sampling technique was used to select 15 extension staff from the three fisheries zones of the state. The 177 members of fish farmers co-operative consists of proportionately sampled 105 extension contact and 72 extension non-contact, while the 23 non-members of fish farmers co-operatives is made up of proportionately sampled 10 extension contact and 13 extension noncontact, giving a sample size of 115 extension contact and 85 extension non-contact fish farmers.

Data were collected from the fish farmers and extension personnel with two types of structured and validated questionnaires alongside situational observations during the dry season of November 1997 and February 1998. This is to ensure easy accessibility to those fishing areas usually cut off during the rainy season. Data were collected on variables as types of fisheries technologies extended, number of technologies adopted, age, farm income, farm size, organisational membership, attitude towards change, education, occupation, and contraints to fisheries development in the state.

Data were analyzed using descriptive statistics, $Z$ - test and Ordinary Least Squares (OLS) Multiple Regression Model. Z-Statistic was used to verify differential impact of Imo State ADP fisheries extension Programme on adoption levels of the recommended fisheries technologies between Imo ADP contact and non-contact farmers (hypothesis 1). Z - statistic is mathematically represented as; 
$Z=$

$$
\frac{\underline{x}_{1}-x_{2}}{n_{1} s_{1}^{2}+n_{2} s_{2}^{2}}
$$

$n_{1} n_{2}$

Where, $Z$ = value for judging mean difference of the statistical significance.

$\mathrm{x}_{1}=$ mean level of improved technologies adopted by the extension - contact farmers.

$x_{2}=$ mean level of improved fisheries technologies adopted by extention non-contact farmers.

$s_{1}{ }^{2}=$ variance from mean level of improved fisheries technologies adopted by the contact farmers

$\$_{2}^{2}=$ vananow from mean level of improved fisheries technologies adopted by the non-contact farmers

$n_{1}=$ number of contact farmers

$n_{2}=$ number of non-contact farmers.

The degree of association or relationship between fish farmers' personal and farm enterprises characteristics and their levels of adoption of improved fisheries technalogies were determined using the Ordinary least squares multiple regression technique. The Model is implicitly specified as follows; $Y=f\left(X_{1}, X_{2}, X_{3}, X_{4}, X_{5}, X_{6}, D, e\right)$ Where $Y=$ index representing level of adoption of improved fisheries technologies measured by the number of improved fisheries technologies adopted by the fish famer.

$x_{1}=$ Age in years

$X_{2}=$ Farm income (Value of Sales of fish in naira).

$X_{3}=$ Farm size (fish population) 
$x_{4}=$ Level of social organisational membership, measured on a four point scale of ordinary member $=1$, financial member $=2$, committee member $=3$ and member of the executive $=4$ $x_{5}=$ Attitude or orientation of fish farmers towards change in agriculture, measured on a three point scale of agree (1), undecided (2) and disagree (3) for the farmers reactions to both positive and negative items constituting the attitude scale.

$x_{6}=$ Level of education in years

$D=$ Dummy representing main occupation, which takes the value of unity where main occupation is fishing, and zero otherwise.

$e=$ errorterm.

Four functional forms of the model, linear, semi-log, CobbDouglas and exponential were fitted to determine the equation that best fit the data. It is expected, a priori that, income, farm size, level of organisational membership, attitude towards change and level of education would be positively related, while age would be negatively related to level of adoption of improved fisheries technologies in the state. The magnitude of the coefficients of all the explanatory variables are expected to be significantly related to level of adoption of improved fisheries technologies in Imo State.

\section{RESULTS AND DISCUSSIONS}

Determination of Levels of Adoption of recommended fisheries technologies

The levels of adoption of the seven recommended technologies of pumps for cropping fish ponds, canoe and nets, hook and line, traps, spears, altona type smoking kiln and ice for preservation while fishing were established by calculating individual scores in descending order of magnitude for the technologies (Table 1). Using an interval of 8 , fish 
farmers were grouped into four major adopter categories of Laggards, Late adopters, early adopters and innovators (Monu and Omole, 1983). Laggards were fish farmers who adopted less than 2 out of the seven technologies or had total scores of less than 8 out of the maximum of 35 points, while late adopters were those whoadopted 2 to 3 of the technologies. Early adopters were fish farmers who adopted 3 to 5 , while innovators were fish farmers who adopted 5 to 7 of the technologies or had total scores of between 27 and the maximum of 35 points. There were more late adopters $(50.5 \%)$ than early adopters $(13.5 \%)$ and innovators $(5.5 \%)$. The mean score on adoption scale was 6.23 out of 35 possible points while the adoption index was 0.18 , indicating that the level of adoption is unsatisfactory to cope with the problem of low fish output in Imo State. This result suggests that the fisheries extension service in the state is not effective. The low level of adoption may be as a result of the problem of non-availability of recommended fishing material for continued usage. Despite the result of low level of adoption, there has been a relative change in the knowledge gain, attitude and fishing behaviours of farmers in the state, as can be seen from the results of the mean level of adoption and adoption index of the extension contact and non-extension contact fish farmers, whichare higher for extension contact farmers. The differential adoption levels of the extension contact and non-extension contact fish farmers were tested for significance, using $Z$ statistic and the result produced a $Z$ - value of 4.833 which is significant at 0.05 level implying that Imo State Fisheries extension programme has a differential impacts on the different fish farmer categories. Thus, hypothesis 1 , which states that Imo State fisheries extension programme has no significant difference on the impact made on the different fish farmer categories, is hereby rejected. Though the activities of the extension service on the fish farmers generally is not satisfactory, the extension contact fish farmers have gained tremendously judging from their higher adoption levels. 
Table 1 Distribution of Fish Farmers by scores on adoption scale

Adopter

categories

and Scores

Laggards

(0-8)

ADP

Contact

Non-
All

Rel. Freq. Freq Rel. Freq Freq. Re!. freq

$\begin{array}{llllll}12 & 10.4 & 49 & 57.6 & 61 & 30.5\end{array}$

Late adopters

(9-17)

71

Early adopters

(18-26)

$22 \quad 19.1$

5

5.9

27

13.5

Innovators

(27-35)

$10 \quad 8.7$

Total

115100

1

Mean

$15.69^{*}$

Adoption Index 0.45

(Mean/Total Scores)

* Mean adoption level significant at $5 \%$.

Source: $\quad$ Survey data, November 1997 - February 1998.

Factors affecting the effectiveness of fisheries extension programme in Imo state

Statistically, the linear function produced more significant variables at both $5 \%$ and $1 \%$ levels, and has highest value of coefficient of multiple detemination, $\mathrm{R}^{2}$ and thus forms the lead equation used for the discussion (Table 2). The result indicates that farm income of the fish farmer and his level of organisational membership are positive and highly significant at $1 \%$, while the coefficients of farm size, attitude towards change, level of education and main occupation are also positive and significant at $5 \%$ level, leading to the rejection of the hypothesis 2 with respect to farm in come, level of organisational membership, farm size, attitude towards change, level of education and main occupation. The co-efficient of age 
variable is negative and insignificant at $5 \%$ level. The hypothesis 2 which states that there is no significant relationship between fish farmers' personal and farm enterprises characteristics and their levels of adoption of improved fisheries technologies was therefore accepted forage. This implies that older farmers seemed to be some what less inclined to adopt recommended fisheries technologies like their younger counterparts. The degree of effect of this factor (age) is not enough to make real differences in their adoption behaviour. Nweke (1981) reported similar findings in his earlier studies on adoptionof improved farm practices.

The significance of farm income, implies that farmers without sound economic standing cannot adopt the recommended fisheries technologies, because the technologies are entirely new to the farmer and represents additional expenditure. Higher farm income levels facilitates the acquisition of these new methods and materials, while that of farm size reveals that as a farmer's farm size increases, he tends to adopt more fisheries technologies. Similar findings have been reported by earlier studies (Ekpere, 1976), who asserted that operators of large scale farms should have more flexibility and opportunity to use new practices on a trial basis, and more ability to deal with risk and uncertainty associated with innovation adoption.

The significance of level of organisational membership such as fish farmers' co-operative association reveal that social organisations serve as a forum through which farmers could exchange ideas and learn about new farm practices. Such knowledge leads to adoption, and the more social organisations a farmer belongs to, the more likely he will be predisposed to adopt new farm practices. Abd-Ella and Hoiberg (1981) reported similar findings where they indicated that learning and adoption of improved practices tend to be facilitated by the existence and participation of farmers in organised groups.

The significance of the co-efficient of attitude towards change implies that when other variables were controlled, a favourable 
disposition towards agricultural innovations encourages farm practice adoption. This finding agrees with that of Williams and Williams (1972), who indicated that attitude is a factor which predisposes a farmer to learn about and adopt new ideas.

The significance of the coefficient of level of education suggests that better educated farmers will tend to adopt more recommended fisheries technologies extended by the extension service in the state. Education arms the farmer with the ability to seek and obtain information about improved practices. This result is consistent with the view of Nweke (1981), that literate farmers are less skeptical of new ideas and are able to evaluate available information on new technologies.

Significance of the coeffiecient of main occupation implies that a farmer whose main occupation is fish farming is ever ready to adopt recommended practices in fish farming to improve his output level than farmers who take fish farming as part time occupation. 
Tabie 2 Regression results on fish farmers personal and farm enterprise characteristics, and adoption levels of recommended fisheries technologies.

Explanatory Linear Cobb

Variables

Intercept

Age $\left(X_{1}\right)$

Farm $\left(\mathrm{X}_{2}\right)$

Income

Farm Size $\left(\mathrm{X}_{3}\right)$

Level of organiz-

- Douglas

$1.056 \quad 1.001$

$(2.085)^{*}(1.023)$

$-2.067-0.104$

$(-1.249)(-1.251)$

$0.327 \quad 0.036$

$(3.594)^{* *}(1.296)$

$1.299 \quad 0.023$

$(2.155)^{*}(3.665)^{* *}$

ational

membership $\left(X_{4}\right) 0.9170 .017$

Attitude towards

$(3.295)^{* *}(2.097)^{*}$

$4.252 \quad 1.102$

(1.087) (1.195)

Change $\left(X_{5}\right) \quad 0.644 \quad 0.107$

$(2.012)^{*}(1.376)$

Level of education
$\left(x_{6}\right)$
$1.447 \quad 0.066$
Main Occupation
$(2.399)^{\star}(1.281)$
(D)
$1.227 \quad 0.004$
$(2.451)^{*}(3.069)^{* *}$
$2.102 \quad 1.221$
(1.591) $(2.098)^{*}$
$1.198 \quad 3.331$
$(2.385)^{*}(1.327)$
$\mathrm{R}^{2}$
$0.762 \quad 0.531$
$\mathrm{F}$
$88.016 \quad 31.016$
$N$
200200
0.311
0.333
$12.328 \quad 13.699$
$200 \quad 200$

$0.791 \quad 2.241$

(1.418) (1.218)

Semi- Exponential

Jog function

$0.222 \quad 0.328$

$(1.009)(0.894)$

$-1.037-0.297$

$(-1.111)(-1.479)$

$\begin{array}{ll}3.113 & 0.337\end{array}$

$(1.065)(1.196)$

$1.397 \quad 1.113$

$(2.327)^{*}(2.594)^{* *}$

Numbers in Parentheses are t-values

* $t$-values significant at $5 \%$

${ }^{* *} t$ - values significant at $1 \%$

Source: Computed from survey data, November 1997-February 1998. 


\section{Constraints to fisheries development in Imo State}

Table 3 reveals that lack of credit facilities, inadequate storage facilities, inadequacy high costs of fishing materials and high cost of manual cropping of ponds were identified by $92 \%, 80 \% 67.5 \%$ and $49 \%$ of the respondents respectively, as the major constraints to fisheries development in Imo State. Other constraints reported include lack of appropriate technology experts $(28 \%)$, inadequacy of technicians for repairs and maintenance of fishing implements $(17.5 \%)$, inadequate motivation for extension personnel $(7.5 \%)$, inadequate transport facilities $(5.5 \%)$, absence of strong co-operative societies $(4.5 \%)$ and incompatible sizes of modern smoking kiln $(2.0 \%)$.

Table 3. Distribution of respondents by identified constraints to fisheries development in Imo State

Identified

Frequency

Relative Frequency

Constraints

Lack of credit facilities 185

92.0

Inadequacy/ high costs

of fishing materials 135

17.5

Inadequate storage

facilities

160

80.0

Inadequate motivation for

extension personnel 15

7.5

Incompatible sizes of

smoking kiln

High cost of manual

cropping of ponds

98

49.0

Absence of strong

co-operative societies 9

43.5

Inadequate transport

facilities

Lack of appropriate technology experts

Source:

Survey data, November 1997 - February 1998. 


\section{POLICY IMPLICATIONS}

The findings of this study have fundamental implications which indicate the need for policy in the following areas.

The Ministry of Agriculture Fisheries extension division should organise in-service training programmes for the extension staff to adequately equip them with current teaching techniques.

Fish Farmers do cherish and indicate their desire for a strong social organisation, such as co-operative fish farmers association devoid of people with dubious intentions. The societies as they stand currently are incapable of acting as a forum for communicating effectively with the fish farmers. There is therefore the need to strengthen co-operative societies.

There is need to train appropriate technology experts to correctly determine the farmers technological needs, their available mental and material resources, and based on these information select an appropriate technology for them. This becomes pertinent in view of the fact that some forms of technology are finding their ways to areas where they are not needed and where the socio-cultural and economic status of the farmers cannot support them.

Modern smoking kiln should be built in different sizes to suit the demand of any community and provided in major fishing communities in the state.

The use of water pumps in croppng natural ponds should be encouraged by subsidizing its price, so as to reduce extensive human labour wasted by manual cropping of ponds.

\section{CONCLUSIONS}

The fisheries extension programmes in Imo State have made limited educational impact on the numerous fish farmers in the state. The fisheries division was successful in creating awareness of fisheries extension programmes, but failed to follow up with sustained 
educational visits to fish farmers and provision of needed fisheries inputs.

Sustained extension efforts were deficient in the areas of provision of more educational visits to fish farmers supported with lectures, seminars and demonstrations. These are necessary to enable the fish farmers increase the level of their fish production in Imo State.

Any policy on fisheries development must consider the important personal and farm enterprises characteristics of fish farmers which influence adoption, for it to succeed. The adoption of improved fisheries technologies by the fish farmers will ensure sustainable productivity and fisheries development in the face of increasing demand for fish in Nigeria.

\section{REFERENCES}

\section{Adb-Ella, M.M and E.O. Hoiberg (1981). "Adoption}

behaviour in family farm systems. An lowa study" Rural Sociology, 46 (1), $42-61$.

Akinbode, I. A. (1976). "The organisation and effectiveness of the agricultural extension service in Nigeria" Agricultural Administration, 3 (4), 271-281.

Asiabaka, C.C (1995). Factors influencing the adoption of cassava plant protection technologies among farmers in Nigeria. IITA Benin ESCAPP, 44-58.

Bennett, C.E. (1977). Analyzing impacts of extension programs, Washington D.C. Extension service, U.S. Department of Agriculture.

Blackenburg, P.V. (1994) Agricultural Extension system in some African and Asian Countries: An analysis of country reports. FAO economic and social development paper (46): 55

Borgstorm, G. (1991).. "Fisheries in World Nutrition" Fishing News International, 1 (1).

Brown, L.R (1963). "Land and Food; Looking ahead at 
World Food needs, protein deficits" Foreign Agricultural Reports, 11, 38.

Cornea, M.M. and B.J Tepping (1977). A system for Monitoring and Evaluating Agricultural Extension Projects. World Bank Staff working paper No. 272, Washington D.C.: The World Bank.

David - West, T (1982). Problems and Prospects of Livestock Development in Nigeria. Federal Department of Livestock, P.2

Davie, L (1975) Shapes - Shared Process Evaluation System: Occassional Paper (5) Kalamazoo, Western Michigan University. The Evaluation Centre.

Ekpere, J.A. (1976). "Organisational Determinant of Differential Programme effectiveness in extension service" Journal of Rural Economics and Development, 10 (1).

FAO (1970). Development Aid in Agriculture Agricultural

Development. A review of FAO Field Activities, Basic Study No. 23, P.3

FAO (1981). Agriculture Towards 2000, Rome, P. 82.

Nweke, F. I. (1981) Determinants of Agricultural progressivenss in the small Holder Cropping System of South-Eastern Nigeria and Consequences for Research and Extension Administration. Agricultural Administration 8(3), $163-176$.

Kanter, D.L. (1982). "How agents and clients view Programmes" Journal of Extension (19): 4-9

Kesley, I.D. and C.C. Hearne (1965). Cooperative extension work. Third edition. Comstock Publishing association. A division of cornell Univerisity Press, Itacha, New York.

Machenna, C. (1981). "Making evaluation manageable Journal of extension (19): $9-14$.

Monu, D.E. and M.M. Omole (1982). "Sources of farm information among Nigeria cocoa farmers" Journal of Agricultural Administration 9 (12): 
Obibuaku, L.O. and G.D Hursh (1983) "Farm Practice and Adoption in the Eastern States of Nigeria" Agricultural Administration. 1 (2): 115-123

Seepersad, J and T.H Henderson (1984). "Evaluating Extension Programmes" PP. 184 - 196.

Steel., S.M. (1975). Six dimensions of programme effectiveness (Evaluation series) Madison, Wisc: Division of Program and Staff development, Univerisity of WInsconsin Extension.

Tyler, R.W. (1950) Basic Principles of Curriculum and Instruction. Syllabus for Education 260. Chicago, Illinois. The University of Chicago Press.

Williams, S. K.T and C.E Williams (1972). "The relationship of farmers characteristic to the sources of information on improved farm practices in Western State of Nigeria". Bulletin of Rural Economics and Social Science: 6 (2); $162-186$.

Young, R.E. and C.J. Canningham (1977). Evaluation Output Measures as identified by extension clientele. Columbus: Ohio State University, Co-operative extension services. 